\title{
Inhibition of Growth and Nucleic Acid Synthesis in Zinc-deficient Mycobacterium smegmatis
}

\author{
By A. B. HARRIS \\ Northern Polytechnic, Department of Home Economics, Dietetics and \\ Institutional Management, Holloway, London, N. 7
}

(Accepted for publication 25 November 1968)

\begin{abstract}
SUMMARY
The growth of Mycobacterium smegmatis was inhibited by lack of zinc in a glycerol + asparagine medium depleted of trace metals but enriched with iron. Addition of zinc to this medium supported full growth of the organism. Both zinc-deficient and zinc-replete cultures had the same exponential doubling time. In zinc-deficient organisms the synthesis of RNA and DNA varied with growth rate in a manner typical for nutrient-induced decreases in a variety of organisms. Zinc-deficiency led to inhibition of nicotinamide synthesis and an increase in phosphate storage as compared with zinc-replete cultures. The $\mathrm{pH}$ value of zinc-deficient cultures was preponderantly alkaline. The results are discussed with reference to the metabolic role of zinc ions, and the effects of zinc deficiency is compared to the effects of iron deficiency as previously reported for the same organism.
\end{abstract}

\section{INTRODUCTION}

In a previous paper (Harris, 1967) the effect of iron deficiency on nucleic acid synthesis in submerged cultures of Mycobacterium smegmatis was discussed. Inhibition of growth in submerged culture of $M$. smegmatis, caused by lack of iron, is associated with a specific inhibition of DNA synthesis (Harris, 1967). Furthermore, deficiency of iron induces inhibition of DNA synthesis before inhibition of growth. Thus, in iron-deficient cultures of $M$. smegmatis, DNA is more sensitive to growth-rate changes than would be expected from the widely confirmed rules formulated by Herbert (196I) and from other work in this field (Kjeldgaard, 196I). These rules, however, were derived from studies of growth rate changes induced by changes of availability of non-mineral nutrients.

In the past, zinc-deficiency has been shown to be related to a loss of ability to metabolize carbohydrate (Webley, Duff \& Anderson, 1962) which is perhaps related to the presence of zinc in many enzymes associated with carbohydrate metabolism (Stein \& Fischer, 1960; Dixon \& Webb, 1964; Cregolin \& Singer, 1963); to distorted morphology (Webley, 1960; Herbert, I96I; Winder, O'Hara \& Ratledge, 196I), and to increase in phosphate storage (Winder \& Denneny, 1959; Winder \& O'Hara, 1962). Comparative studies of the exponential phase of growth of Mycobacterium smegmatis or other organisms in zinc-replete and zinc-deficient cultures have not been made.

In the present work exponentially growing submerged Mycobacterium smegmatis cultures were used to determine the effect of zinc deficiency upon the growth and 
nucleic acid metabolism of this organism. The conditions of growth and the methods of assay were like those used in the previous study of iron deficiency of this organism (Harris, 1967).

\section{METHODS}

\section{Extraction procedures and assays}

Mycobacterium smegmatis was grown in a chemically defined glycerol + asparagine medium depleted of trace metals and harvested as previously described (Harris, 1967). Depleted media were enriched with ferrous sulphate $\left(\mathrm{FeSO}_{4} \cdot 7 \mathrm{H}_{2} \mathrm{O}\right.$, Analar Grade) solution to give a concentration of $2 \cdot 0 \mu \mathrm{g}$. $\mathrm{Fe}^{2+} / \mathrm{ml}$. Zinc-replete medium was prepared by adding a solution of zinc sulphate $\left(\mathrm{ZnSO}_{4} \cdot 7 \mathrm{H}_{2} \mathrm{O}\right.$, Analar Grade) to the ironenriched media to give a concentration of $0.4 \mu \mathrm{g}$. $\mathrm{Zn}^{2+} / \mathrm{ml}$.

Materials for assay were extracted from freeze-dried samples of organisms as described by Harris (1967).

The nucleic acids were assayed spectrophotometrically and expressed in terms of phosphorus (Logan, Mannell \& Rossiter, 1952; Harris, I967).

The water and trichloroacetic acid extracts of the organism were assayed for nicotinamide by a cyanide addition reaction (Ciotti \& Kaplan, 1957).

The term 'insoluble phosphate' was first used by Winder \& O'Hara (I962) to describe phosphate found in the nucleic acid extracts of surface cultures of Mycobacterium smegmatis. In the present work, this contribution was assayed by a modified method, since it was found that when the incinerated nucleic acid extracts were not hydrolysed before phosphate assay, variable results were obtained. Unless this precaution is taken, as described below, inorganic orthophosphate is determined, but pyrophosphate is not (A. B. Harris, unpublished results). Furthermore, the absorbancy of the phosphate molybdate complex upon which the assay depends, varies with time of standing; consequently, readings were taken at a fixed time, $24 \mathrm{hr}$ after mixing of the reagents with the nucleic acid extracts.

Pooled samples of the nucleic acid extracts $(0.5 \mathrm{ml}$. each) were incinerated with concentrated sulphuric acid (0.1 ml.) and hydrogen peroxide $(0.2 \mathrm{ml} ., 30 \mathrm{vol}$.) until fumes were seen. After cooling, water was added ( $\mathrm{I}$ to $5 \mathrm{ml}$.) and the mixture heated $\left(2 \mathrm{hr}, 100^{\circ}\right)$ to hydrolyse polyphosphate formed by the incineration; the total phosphate was then determined (Le Page, 1949). From this value was subtracted phosphate contributed by the nucleic acids (Harris, 1967) to give insoluble phosphate. This phosphate is not part of the phosphate chain of the nucleic acids, in $3^{\prime}, 5^{\prime}$ diester linkages with ribofuranose (RNA); and 2-deoxyribofuranose as found in DNA (Watson \& Crick, 1953), but it is extracted with the nucleic acids.

\section{RESULTS}

\section{Growth of Mycobacterium smegmatis}

Growth departed from the exponential at about seven generation times after inoculation in zinc-replete and in zinc-deficient media. In both cultures the exponential doubling time, as with iron-deficient cultures, was $7 \cdot 0 \pm 0.5 \mathrm{hr}$. In zinc-deficient cultures exponential growth ceased abruptly (Fig. I), indicative of the exhaustion of a single nutrient (Herbert, 196I), which was zinc in this case. 


\section{Synthesis of RNA in post-exponential growth of Mycobacterium smegmatis}

The rate of synthesis of RNA in zinc-replete cultures of Mycobacterium smegmatis slowed to a greater extent than did the growth rate, as shown by the decrease in the values of P-RNA/unit dry wt organism. This result is typical of bacteria when undergoing a 'shift-down' in growth rate (Herbert, I96I). This effect was shown by $M$. smegmatis grown in zinc-replete media (Table I). However, the content of P-RNA/ dry wt organism in zinc-deficient cultures did not appreciably fall during the inhibited phase.

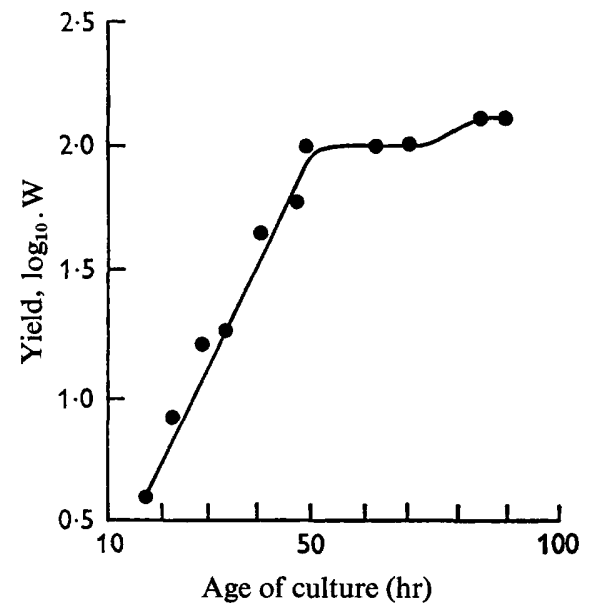

Fig. I. Typical growth curve of Mycobacterium smegmatis grown with insufficient zinc in a minerally depleted glycerol+asparagine medium, at $37^{\circ}$, containing $2 \cdot 0 \mu \mathrm{g}$. $\mathrm{Fe}^{2+} / \mathrm{ml}$., but no added zinc. Organisms were washed, freeze-dried, and weighed. The yield is expressed $\mathrm{W}=\mathrm{mg}$. dry wt organism from $80 \mathrm{ml}$. culture.

\section{Synthesis of DNA during post-exponential growth of Mycobacterium smegmatis}

DNA synthesis is less sensitive than RNA synthesis to growth-rate changes (Herbert, 1961). The content of P-DNA of Mycobacterium smegmatis grown in zinc-replete media appeared to increase during the transition from declining phase to stationary phase (Table I). In 'shift-down' experiments the content of DNA of bacteria increases (Herbert, 196I). In the stationary phase of M. smegmatis grown in zinc-deficient medium the content of DNA was constant (Table I). Thus whereas a shift-down resulting from carbon and nitrogen deficiency led to the usual DNA response in $M$. smegmatis, a shift-down resulting from zinc deficiency led to a balanced inhibition of DNA synthesis. However, a small growth of the organism persisted after the transition from the exponential phase, i.e. a slight shift-up effect was produced. This should lead to a decrease in DNA content of the organisms, but this effect, although shown in several experiments, was not marked (Table I).

Synthesis of RNA and DNA during exponential growth of Mycobacterium smegmatis

According to Herbert (196I), an identical growth rate should lead to a similarity of chemical composition. Exponentially growing Mycobacterium smegmatis in zincreplete and zinc-deficient media showed nearly identical contents of RNA and DNA 
(Table 2). Furthermore, the content of RNA and DNA increased in both cultures during the exponential phase, and then decreased as the decline phase was approached. Thus, zinc deficiency affected the rate of synthesis of RNA and DNA in the same way as a shift-down induced by carbon + nitrogen deficiency, in the zinc-replete cultures (Table 2). Irrespective of the zinc-content of the media the deceleration in growth rate was anticipated by a decline in the rate of DNA and RNA synthesis, as predicated from Herbert's rules (196I). However, RNA synthesis is usually more sensitive than DNA synthesis to changes in the rate of growth (Kjeldgaard, 196I; Buetow \& Levedahl, 1962). This distinction was not found with cultures of M. smegmatis (Table 2; Harris, 1967).

Table I. Yields of organism and nucleic acid content of Mycobacterium smegmatis

Mycobacterium smegmatis was grown in $80 \mathrm{ml}$. glycerol+asparagine medium at $37^{\circ}$. The zinc-replete medium contained $0.4 \mu \mathrm{g}$. $\mathrm{Zn}^{2+} / \mathrm{ml}$. and $2 \cdot 0 \mu \mathrm{g}$. added $\mathrm{Fe}^{2+} / \mathrm{ml}$. The zincdeficient medium contained $2 \cdot 0 \mu \mathrm{g}$. Fe ${ }^{2+} / \mathrm{ml}$. but no added zinc. The bacteria were harvested at the times indicated, freeze-dried, weighed, and their nucleic acids extracted.

\begin{tabular}{|c|c|c|c|c|c|c|}
\hline \multicolumn{3}{|c|}{ Zinc-replete medium } & & \multicolumn{3}{|c|}{ Zinc-deficient medium } \\
\hline \multirow{2}{*}{$\begin{array}{c}\text { Yield } \\
\text { (mg. dry wt } \\
\text { bacteria/ } \\
80 \text { ml. } \\
\text { culture) }\end{array}$} & \multicolumn{2}{|c|}{$\mu \mathrm{g} . \mathrm{P} / \mathrm{mg}$. dry wt bacteria } & \multirow{2}{*}{$\begin{array}{c}\text { Age of } \\
\text { culture } \\
\text { (hr) }\end{array}$} & \multirow{2}{*}{$\begin{array}{c}\text { Yield } \\
\text { (mg. dry wt } \\
\text { bacteria/ } \\
80 \mathrm{ml} \text {. } \\
\text { culture) }\end{array}$} & \multicolumn{2}{|c|}{$\mu \mathrm{g} . \mathrm{P} / \mathrm{mg}$. dry wt bacteria } \\
\hline & P-DNA* & P-RNA* & & & P-DNA* & P-RNA* \\
\hline 192 & $2 \cdot 70$ & $4 \cdot 95$ & 45 & 102 & $2 \cdot 3$ & $4 \cdot 5$ \\
\hline 286 & $2 \cdot 55$ & $5 \cdot 05$ & 50 & 106 & $2 \cdot 3$ & $5 \cdot 0$ \\
\hline 285 & $2 \cdot 55$ & $5 \cdot 27$ & 53 & II 8 & $2 \cdot 3$ & $4 \cdot 5$ \\
\hline 348 & $2 \cdot 55$ & $4 \cdot 80$ & 56 & 142 & $2 \cdot 3$ & $5 \cdot I$ \\
\hline 442 & $2 \cdot 70$ & $4 \cdot 87$ & 70 & 148 & $2 \cdot I$ & $5 \cdot 0$ \\
\hline 498 & $3 \cdot 00$ & $4 \cdot 72$ & 75 & 216 & $2 \cdot 0$ & $4 \cdot 7$ \\
\hline 562 & $2 \cdot 85$ & $4 \cdot 40$ & 98 & 226 & $\mathrm{I} \cdot 8$ & - \\
\hline
\end{tabular}

* Concentrations of RNA, DNA as atoms of phosphorus (Logan, Mannell \& Rossiter, 1952).

\section{Table 2. Yield of organism and nucleic acid content of Mycobacterium smegmatis during exponential growth}

Mycobacterium smegmatis was grown in the glycerol + asparagine medium at $37^{\circ}$. The zincreplete medium contained $0.4 \mu \mathrm{g}$. added $\mathrm{Zn}^{2+} / \mathrm{ml}$., and $2 \cdot 0 \mu \mathrm{g}$. added $\mathrm{Fe}^{2+} / \mathrm{ml}$. The zincdeficient medium contained $2 \cdot 0 \mu \mathrm{g}$. $\mathrm{Fe}^{2+} / \mathrm{ml}$., but no added zinc. The bacteria were harvested at the times indicated, freeze-dried, weighed, and their nucleic acids extracted.

\begin{tabular}{|c|c|c|c|c|c|c|}
\hline \multirow{3}{*}{$\begin{array}{c}\text { Age of } \\
\text { culture } \\
\text { (hr) }\end{array}$} & \multicolumn{3}{|c|}{ Zinz-replete media } & \multicolumn{3}{|c|}{ Zinc-deficient media } \\
\hline & \multirow{2}{*}{$\begin{array}{c}\text { Yield } \\
\text { (mg. dry wt } \\
\text { bacteria/ } \\
80 \text { ml. culture) }\end{array}$} & \multicolumn{2}{|c|}{ 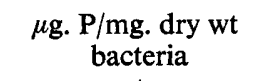 } & \multirow{2}{*}{$\begin{array}{c}\text { Yield } \\
\text { (mg. dry wt } \\
\text { bacteria/ } \\
80 \text { ml. culture) }\end{array}$} & \multicolumn{2}{|c|}{ 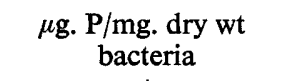 } \\
\hline & & P-DNA & P-RNA & & P-DNA & P-RNA \\
\hline & \multicolumn{6}{|c|}{ Cultures in $160 \mathrm{ml}$. medium } \\
\hline 18 & 3.5 & $2 \cdot 9$ & $6 \cdot 9$ & $3 \cdot 9$ & $2 \cdot 8$ & $7 \cdot 5$ \\
\hline 23 & $7 \cdot 6$ & $2 \cdot 9$ & $7 \cdot 8$ & $7 \cdot 9$ & $2 \cdot 8$ & $6 \cdot 9$ \\
\hline 28 & $16 \cdot 8$ & $3 \cdot 5$ & $7 \cdot 8$ & $15 \cdot 8$ & $3 \cdot 6$ & $7 \cdot 2$ \\
\hline 34 & $15 \cdot 3$ & $2 \cdot 9$ & $7 \cdot 5$ & $18 \cdot 2$ & $3 \cdot I$ & $7 \cdot 6$ \\
\hline $4 I$ & $35 \cdot 7$ & $3 \cdot 2$ & $6 \cdot 9$ & $37 \cdot 8$ & $3 \cdot 2$ & $5 \cdot 5$ \\
\hline 48 & $57 \cdot 7$ & $2 \cdot 7$ & $6 \cdot I$ & $56 \cdot 2$ & $3 \cdot 0$ & $5 \cdot 7$ \\
\hline
\end{tabular}




\section{Synthesis of nicotinamide and storage of phosphate in exponential and post-exponential growth of Mycobacterium smegmatis}

During exponential growth of Mycobacterium smegmatis the synthesis of nicotinamide (chiefly as nicotinamide adenine dinucleotide, the rest in nicotinamide adenine dinucleotide phosphate and nicotinamide mononucleotide) increased more quickly than growth rate, leading to an increase of content of nicotinamide/dry wt organism (Table 3). This result was found for cultures containing insufficient and sufficient zinc. The nicotinamide content appeared to reach a maximum just after the end of the exponential phase in both types of culture, and decreased in the decline phase (Table 3 ). The relationship between growth rate and phosphate storage appeared to be obscure (Table 3), there being no obvious trend in the zinc-replete cultures. The effect of zinc-deficiency, however, upon this insufficiently characterized material (Winder \& O'Hara, 1962) was to increase the content as growth persisted (Table 3).

\section{Table 3. Nicotinamide and phosphate content of Mycobacterium smegmatis during exponential and post-exponential growth}

Mycobacterium smegmatis was grown in $80 \mathrm{ml}$. glycerine+asparagine medium at $37^{\circ}$. The zinc-replete medium contained $2 \cdot 0 \mu \mathrm{g}$. $\mathrm{Fe}^{2+} / \mathrm{ml}$. and $0 \cdot 4 \mu \mathrm{g}$. $\mathrm{Fe}^{2+} / \mathrm{ml}$. The zinc-deficient medium contained $2 \cdot 0 \mu \mathrm{g}$. $\mathrm{Fe}^{2+} / \mathrm{ml}$. but no added zinc. The bacteria were harvested at the times indicated, freeze-dried, weighed, and their nicotinamide and phosphate extracted.

\begin{tabular}{|c|c|c|c|c|}
\hline \multirow{3}{*}{$\begin{array}{c}\text { Age of } \\
\text { culture } \\
\text { (hr) }\end{array}$} & \multicolumn{4}{|c|}{ Content of bacteria } \\
\hline & \multicolumn{2}{|c|}{$\begin{array}{c}\text { Nicotinamide* } \\
(\mu \mathrm{g} . / \mathrm{mg} . \text { dry wt bacteria })\end{array}$} & \multicolumn{2}{|c|}{$\begin{array}{c}\text { Phosphate } \dagger \\
\text { ( } \mu \text { g. P/mg. dry wt bacteria) }\end{array}$} \\
\hline & $\mathrm{Zn}+$ & $\mathrm{Zn}-$ & $\mathrm{Zn}+$ & $\mathrm{Zn}-$ \\
\hline 18 & $1 \cdot 3$ & - & - & - \\
\hline 23 & $I \cdot 0$ & - & $4 \cdot 7$ & $4 \cdot 2$ \\
\hline 28 & $1 \cdot 2$ & $1 \cdot 3$ & $5 \cdot 0$ & $6 \cdot 2$ \\
\hline 34 & $1 \cdot 5$ & $I \cdot 5$ & $7 \cdot I$ & $7 \cdot 2$ \\
\hline $4 I$ & $1 \cdot 5$ & $I \cdot 7$ & $4 \cdot 2$ & $7 \cdot 1$ \\
\hline 48 & $1 \cdot 7$ & $1 \cdot 6$ & $6 \cdot 2$ & $6 \cdot 7$ \\
\hline 64 & $1 \cdot 8$ & $\mathrm{I} \cdot 7$ & $5 \cdot 8$ & $9 \cdot 3$ \\
\hline $7 I$ & $I \cdot 2$ & $I \cdot 4$ & $5 \cdot 3$ & $I I \cdot \cdot I$ \\
\hline 85 & $I \cdot 6$ & I $\cdot 3$ & $6 \cdot 3$ & 10 6 \\
\hline $9 \mathrm{I}$ & $I \cdot 2$ & $I \cdot 2$ & $4 \cdot 3$ & $10 \div 3$ \\
\hline
\end{tabular}

* The nicotinamide moiety was extracted by water and TCA (see Methods), and included contributions from NAD, NMN, NADP, as well as the reduced co-enzymes, and was estimated by a cyanide addition reaction (Ciotti \& Kaplan, 1957).

† Phosphate extracted with RNA and DNA but not bound to them, and expressed in atoms of phosphorus (Logan, Mannell \& Rossiter, 1952).

\section{Changes of the $p H$ value of cultures during growth of Mycobacterium smegmatis}

Whereas the $\mathrm{pH}$ value of zinc-replete cultures of Mycobacterium smegmatis remained near neutrality throughout the exponential and decline phases, being slightly acid at the transition between the two phases, zinc-deficient cultures became progressively more alkaline throughout the exponential phase, and more so as growth inhibition persisted. 


\section{DISCUSSION}

Insufficient supplies of zinc, like insufficient supplies of iron (Harris, I967), led to an inhibition of growth of Mycobacterium smegmatis. However, zinc-deficiency did not lead to any specific effect upon RNA and DNA synthesis, whereas iron-deficiency does (Harris, 1967). The present work would appear to indicate that in nucleic acid metabolism, zinc has not a more primary function than has an adequate supply of carbon + nitrogen. Thus, zinc deficiency can be considered similarly to carbon + nitrogen deficiency, and the rules of Herbert (196I) apply to the same extent in zincreplete and zinc-deficient cultures. The composition of bacterial nucleotide and the levels of pools is known to depend on growth rate (Brown, I962). Whether the constancy of the levels of the pool in this case resulted from a relative constancy of the constituents to one another, or a fall in some with a rise in others, cannot be ascertained from these results.

Estimation of the total oxidized nicotinamide (NAD and NADP) showed that the value decreased during zinc inhibition (Table 3). A decrease in nicotinamide nucleotides has been shown to occur in surface cultures of zinc-deficient bacteria (Winder \& O'Hara, I962) though no estimate of pre-inhibition values was made. Brown (1965) found that the total concentrations of nicotinamide mononucleotides varied little despite different physiological activity in germinating pea seeds.

An inhibition of growth on Mycobacterium smegmatis is caused by lack of zinc in the nutrient medium. Since zinc is a constituent of many enzymes, particularly those involved in carbohydrate metabolism (see Introduction), a failure in the production of high-energy phosphate might well be caused by lack of zinc. If this is the mechanism of the effect of zinc deficiency, it might be expected that a decrease of high-energy phosphate would result. Thus, once ATP had been discharged in metabolism to give AMP, polyphosphate and/or inorganic phosphate, it would not be resynthesized, and a higher level of phosphate should be found in zinc-deficient cells. At present it is not clear to what extent the increase of storage of inorganic phosphate found in zinc-deficient cells can be attributed to a breakdown in the utilization of inorganic phosphate. Some speculation has been made for surface cultures of $M$. smegmatis (Winder \& Denneny, 1959).

The chief interest of the effects of zinc deficiency in Mycobacterium smegmatis at present lies in its different effect from iron deficiency in the same organism (Harris, 1967). Lack of iron results in atypical responses of nucleic acid metabolism to growth shifts, zinc-deficiency is more like a carbon + nitrogen deficiency. It is concluded that mineral deficiencies cannot $a$ priori be supposed to present a different class from other nutrient effects, although lack of minerals can lead to specific effects (Harris, 1967).

The author extends his thanks to the Medical Research Council of Ireland and the Inner London Education Authority, for making this work possible, to Mr F. Winder for his interest in it, and to Mrs J. Gibbins for her encouragement. 


\section{REFERENCES}

Brown, E. G. (1962). The acid-soluble nucleotides of mature pea seeds. Biochem. J. 85, 633 .

Brown, E. G. (1965). Changes in the free nucleotide and nucleoside pattern of pea seeds in relation to germination. Biochem. J. 95, 509.

Buetow, D. E. \& Levedahl, B. H. (I962). Decline in the cellular content of RNA, protein and dry weight during the logarithmic growth of Euglena gracilis. J. gen. Microbiol. 28, 579.

CrotTi, M. C. \& Kaplan, N. O. (I957). Procedures for determination of pyridine nucleotides. Meth. Enzymol. 3, 890 .

Cregolin, C. \& Singer, T. P. (1963). The lactic dehydrogenase of yeast. III. D(-)Lactic cytochrome $c$ reductase, a zinc-flayoprotein from aerobic yeast. Biochim. biophys. Acta 67, 201.

Dixon, M. \& WebB, E. C. (1964). Enzymes, pp. 307, 456, 464. London: Longmans.

HARRIS, A. B. (1967). Inhibition of growth and nucleic acid-synthesis in iron-deficient Mycobacterium smegmatis. J. gen. Microbiol. 47, $11 \mathrm{I}$.

HeRBert, D. (196I). The chemical composition of micro-organisms as a function of their environment. Symp. Soc. gen. Microbiol. II, 39.

KJEldgaARD, N. O. (196I). The kinetics of ribonucleic acid and protein formation in Salmonella typhimurium during the transition between different states of balance growth. Biochim. biophys. Acta 49, 64.

Le Page, G. A. (1949). In Manometric Techniques and Tissue Metabolism, 2nd ed. Ed. by W. W. Umbreit, R. H. Burris and J. F. Stauffer, p. 185. Minneapolis: Burgess Publishing Co.

Logan, J. E., Mannell, W. A. \& Rossiter, R. J. (1952). A note on the determination of deoxypentose nucleic acid and pentose nucleic acid in tissue from the nervous system by ultraviolet absorption. Biochem. J. 5x, 480 .

Stein, E. A. \& Fischer, E. H. (1960). Bacillus subtilis, $\alpha$-Amylase, a zinc protein complex. Biochim. biophys. Acta 39, 287.

WATSON, J. D. \& CRICK, F. M. C. (1953). Molecular structure of nucleic acids. Nature, Lond. x71, 737.

Webley, D. M. (1960). The effect of deficiency of iron, zinc and manganese on the growth and morphology of Nocardia opaca. J. gen. Microbiol. 23, 87.

Webley, D. M., Duff, R. B. \& Anderson, G. (I962). The metabolism of iron-, zinc- and manganesedeficient Nocardia opaca. J. gen. Microbiol. 29, 179.

Winder, F. G. \& DENNENY, J. M. (1959). Effect of iron and zinc on nucleic acid and protein synthesis in Mycobacterium smegmatis. Nature, Lond. $184,742$.

Winder, F. G. \& O'HARA, C. (1962). Effects of iron deficiency and of zinc deficiency on the composition of Mycobacterium smegmatis. Biochem.J.82, 98.

Winder, F. G., O'Hara, C. \& RATledge, C. (I96I). Levels of some enzymes in normal, in irondeficient, and in zinc-deficient Mycobacterium smegmatis. Biochem. J. 80, 2 I P. 